\title{
Urban South Africa: An opportunity for liberating theological education
}

\section{Stephan de Beer ${ }^{1}$}

\begin{abstract}
This article proposes the city as an opportunity and resource for liberating theological education. It explores going beyond adding "urban" to theological education as an addendum, but rather to consider "urbanizing" theological education as a whole, in an inclusive way that affirms the interconnectedness of urban-suburban-rural realities. It explores theological education that takes the whole of the urban and global reality, and its implications for local communities and people, seriously as its locus for theological reflection and action. It draws from the person and praxis of Klippies Kritzinger as a metaphor for a spirituality of theological education that is open to the potential liberating effects of the city.
\end{abstract}

Keywords: Theological education, Urban theological education.

\section{Introduction: The city as a resource for liberating theological education}

Conventionally, we will ask: How can the church and theological education place cities more intentionally on their agenda? How should the church and theological education contribute to the transformation of our cities? In response, we even create a specialist field such as "urban theological education", which often tends to become marginal in the greater theological enterprise (Davey 2001:10-13).

This article suggests a prior step, which is to regard the cities of South Africa as an opportunity or resource for liberating theological education, before theological education can be considered as a resource for the liberation of the city. Rather it asks: How can we see the city as a potential resource for liberating and transforming our churches and theological education? How can the voiceless urban masses help shape our theological discourses?

But it is more than just a prior step; it suggests a more comprehensive vision. I speak here not only of what can be conveniently relegated to "urban" theological education, but also of exploring possibilities for urbanising the whole enterprise of theological education, without excluding suburban, rural or other realities, but understanding the ever-increasing interconnectedness of these realities. I speak of theological education that takes the whole of the urban and global reality, and its implications for local communities and people, seriously as its locus for theological reflection and action (cf. Davey 2001:11).

1 Dr Stephan de Beer is Director of the Centre for Contextual Ministry, University of Pretoria, South Africa. He can be contacted at stephan.debeer@up.ac.za. 
It is a vision of theological education that will be liberated in terms of structure, practice, process of learning, and habitus, in the vision of Rebecca Chopp (1991:86-87). Although feminist theologies contributed significantly to theological education, introducing new voices and faces, defining new research areas, providing new resources and models, and offering new languages or visions, Chopp (1991:67-69) reflects critically on the actual contribution of feminist theologies to transforming theological education structurally and otherwise. The city too and urban theology done from below can offer new voices, research areas, resources, languages and visions, but this article proposes a more fundamental liberation of theological education in the vision of Chopp (1991).

This article is in honour of missiologist Klippies Kritzinger. Like a chameleon, Klippies has inserted himself into different urban contexts, moving between worlds and cultures, making space for different and often conflicting voices to be heard, between academia and ecclesia, always seeking to maintain his personal and professional integrity. Towards the end of the article, I would like to draw from his person and praxis as metaphor for a spirituality of theological education that is open to the liberating effects of the city.

\section{Urban South Africa: Contexts of perpetual challenge and change}

\subsection{Socio-political-demographic changes and challenges}

\subsubsection{Changing legislation, changing socio-cultural patterns}

South African cities have undergone major changes in the past two decades. Towards the end of the 1980s, the Group Areas and Influx Control acts were scrapped, paving the way for cities that are more integrated. Black urbanisation was the order of the day and previously "white" urban areas, in inner-city neighbourhoods at least, became integrated and in some cases even changed into predominantly "black" areas, sometimes almost overnight. Many authors have described this changing landscape, particularly in relation to Johannesburg (Swilling et al. 1991; Holland and Roberts 2002; Bremner 2004).

Urban change in most cases preceded ecclesial change. Inner-city contexts like Hillbrow became prophetic in the late 1980s as to the future face of inner-city areas. The church in most instances provided little in terms of a prophetic vision for integration and inclusion. Issues of racial change, socio-economic disparity, the influx of refugees or asylum seekers, and vulnerable street populations were often not proactively addressed by churches in terms of structuring themselves for change. The church followed the political changes, in most cases, instead of providing independent leadership and vision. 
Besides changes prompted by political change, the world in which the church finds itself has also changed culturally, with the dawn of postmodernism and post-postmodernism, and the emergence of a virtual world that creates new ways of relating, new understandings of intimacy, and new ways of being. Places like Braamfontein in Johannesburg, Hatfield in Pretoria, Vilakazi Street in Soweto, Point Road in Durban, and Woodstock in Cape Town, all speak of continuous change and challenge, of death and resurrection, of urban dynamics and forces that shape lives, destinies and neighbourhoods. The church is strangely absent from many of these emerging or decaying realities - if not physically, then in terms of concrete engagement, and sadly, often by design-instead of being a participating, inquisitive, learning and transformational companion.

\subsubsection{Competing visions of urban land use}

With the socio-political changes, changes in urban spatial patterns occurred that also resulted in competing visions of urban land. The contest for space became even more intense than before in terms of land use, affordability and accessibility, over against exclusivity (De Beer 2008).

The Woodlane Village in the eastern suburbs of Pretoria is situated on 70 hectares of vacant land owned by the City of Tshwane (the metropolitan municipality). This land accommodates approximately 3,500 people in a secured informal settlement. It is surrounded by the Woodhill Golf Estate, which commands some of the highest property prices in the city; the Woodlands Boulevard, an upmarket shopping mall; various gated residential estates; and the Moreleta Park Dutch Reformed Church with its 10,000-seat auditorium.

Court cases by resident associations sought the removal of the squatters. Human rights lawyers took the rights of the squatters before the court and won every case. This has become a contest of space between some of the wealthiest landowners in Tshwane, and those who own nothing. The last court ruling instructed the city authorities to create an integrated development plan for this land, indicating the manner in which the informal residents will be integrated into a newly developed, well-designed and sustainable human settlement (Venter 2011a; 2011b).

On both sides of this contest for space are people professing to be Christians. The largest church in the city is separated from Woodlane Village's 3,500 residents by a simple fence. What is the gospel in such a fragmented urban context, in the contest for land and space? And how does it inform our understanding and practice of theological education?

\subsubsection{Urban sprawl and fragmentation versus visions of densification and integration}

City planning in most South African cities allows for rather uncontrolled urban sprawl, despite theoretical visions for the densification of cities, based 
on research outlining the dangers of sprawl, environmentally, but also from the perspective of urban management and social inclusion.

Suburbanisation of cities continues along with the depletion of resources from poorer urban areas such as the inner city. The invention of urban townships to segregate our cities and to keep black citizens from the centres continues to perpetuate deeply divided and fragmented urban spaces and will not change overnight. The reality of existing and new informal settlements contributes to the sprawl, and residents of such settlements remain excluded from access to resources that will sustain livelihoods (Huchzermeyer and Karam 2006).

Also in this regard, the church often fails to provide prophetic and proactive leadership, following the trend to suburbia instead of modelling alternative and perhaps more sustainable ways of urban living. At the root is the church's lack of a clear and bold urban vision. The church and institutions of theological education have not become urban at heart, even if they happen to have an urban location.

In all of the above, increasing (and new) urban fragmentation/s takes place instead of the integration one would think post-apartheid South African society would work towards. The same fragmentation dividing the city is evident in the fragmentation of the inner-city, suburban and township church.

\subsection{Political and institutional changes and challenges}

\subsection{1 (Dis)integrated municipalities}

One of the consequences of political change was the integration of municipalities that were historically divided and decentralised. Whilst this was essential to deracialising the city and to creating an integrated city structure with one economic base, it did not always translate into effective city management. Too often, it seems to have resulted in disintegrated municipalities failing to deliver services especially to the poorest citizens.

The City of Ekurhuleni (the old East Rand of Gauteng) combines more than twenty-seven smaller cities and towns into one metropolitan municipality. Smaller town centres in many of these towns collapsed into ghost towns. Important assets and infrastructure were often neglected through lack of clear vision, political will, or sound planning processes, as well as disinvestment and decentralised responsibilities. Resources and investment have shifted to new centres like Midrand and the envisaged aerotropolis around the O.R. Tambo International Airport, often at the expense of old towns in the municipal area (Wikipedia 2012a).

In rural towns and informal settlements around the country, there are outcries from angry and impatient residents, bemoaning the lack of service delivery and the corruption of local authorities. The situation in the North West Province is a case in point-the Auditor-General in 2011 
recommended a total intervention in the province, suggesting that most of its twenty-five municipalities had serious problems (Parliamentary Monitoring Group 2011).

The church can either be a distant observer of such realities, or respond to a challenge for engagement that will take it beyond its traditional domain into public spaces where political decisions are made, resources allocated, and essential services decided. It is in the public arena that decisions are taken that affect the citizens of the city and the members of churches, for whom the church is taking pastoral responsibility. It is here that the moral, physical and economic fibre of the city is slowly being depleted.

\subsubsection{Discovering (un)democratic government}

Post-apartheid cities introduced democratic government. It is at the level of local government that the frailty of our democracy becomes particularly visible, especially in the break-down in communication between the citizenry and local politicians, and the way in which elected representatives often fail to be accountable to their constituencies. In local government, the elected officials are supposedly representatives of local constituencies, but when they have to weigh the sentiments of the electorate against the sentiments of their party bosses, it is the latter who are usually given priority (Sibalukhulu 2012:34; Lekota 2012:37).

Instead of providing blank mandates to representatives without real checks and balances built into them (representative democracy), a participative democracy will continuously seek to build consensus and a partnership between the citizenry and their elected leaders. It will ensure an active citizenry taking ownership of the affairs of the city, instead of a passive citizenry waiting for government to perform. To what extent does the church participate as an active citizen in local democratic city-making processes?

\subsubsection{The fall and rise of civil society}

Pre-1994, a strong civil society, marked by civic organisations and the anti-apartheid movement, often provided strong leadership for change in the country. Many of the civic leaders of that time graduated into the political or business arena post-1994, and others moved from their original rootedness in the struggling urban place to suburbia, leaving a leadership vacuum at the level of civil society.

However, trade unions, movements like the Treatment Action Campaign and Abahlali baseMjondolo, and sporadic outbursts of civil action in towns and cities across the country are indications that there still is a strong movement for resistance that is able to organise itself against exclusive or oppressive forces. One of the current resurrections of civil society is made evident by the protests against the implementation of the E-Toll system on the roads of Gauteng (Serrao and SAPA 2012). Sometimes this has become too fragmented a movement, however, as it is now driven 
not by a singular mission to dismantle apartheid, but by the multiplicity of challenges facing South African society at all levels.

As part of the reality of post-apartheid South Africa, the church in many ways has failed to consolidate its position and redefine its mission. It is rather fragmented and bewildered without clarity of vision in its public, prophetic role (Sosibo 2012). The church has failed to position itself as part of the broader civil society, which could perhaps help to re-energise the church in its own mission, if it walked alongside those working in the trenches of post-apartheid South Africa, both unmasking the new demons and reconstructing fragmented communities. As a critical companion of strategic and critical processes, and in close solidarity, the church could be(come) partner and servant, without necessarily having to be initiator or leader.

\subsubsection{The absence of and challenge for institutional infrastructure}

Many local urban communities lack institutional infrastructure that will facilitate access to services and resources necessary for holistic well-being and sustainable livelihoods. In post-apartheid urban communities, access to decent education (both pre-, primary and high school), basic health care in general and antiretroviral treatment in particular, recreational facilities, decent and affordable housing, vocational skills and information technology are not only general challenges, but also constitute a crisis in the life of neighbourhoods, families and individuals (De Vos 2012).

The church often possesses the assets - people, land, property, finances, knowledge and skills - that, if unlocked, could help provide the kind of access that will break cycles of poverty and marginalisation. However, such assets are often locked away in certain pockets of the church, and churches in the most struggling parts of the city lack their own institutional capacity to mediate change.

\subsection{Economic and environmental changes and challenges}

\subsubsection{Envisioned economic integration: Between margins and centre}

The integration of municipalities and the demarcation of municipal boundaries also envisioned new economic integration of marginal communities and their citizens (Department of Cooperative Governance and Traditional Affairs n.d.; Nel and Binns 2001). Stinkwater in the north of the City of Tshwane was known as a peri-urban area falling outside the boundaries of the metropolitan area. Political demarcation then integrated Stinkwater into the metropolitan boundaries in 2000 , with a vision for such communities to gain better access to the resource base of the larger metropolitan municipality. In theory, this was a radical and preferred alternative for formerly excluded communities. Whether inclusion into the 
metropolitan area had the desired outcome is questionable, as Stinkwater experiences many of the same vulnerabilities as before.

This raises an important question: How do we plan a city in ways that will help the margins access the centre, or how can new centres be created in the margins? It is simultaneously a theological question because Jesus always gravitated to the margins.

\subsubsection{Investment}

South African cities, even in this time of global recession, have experienced significant investments. The 2010 FIFA World Cup obviously contributed to an environment conducive to investment. In the province of Gauteng and the City of Tshwane developments such as the Gautrain and the injection of R11 billion into government infrastructure in the city centre created an upswing in property prices and in the confidence of banks and investors (Shaw 2005; Ben 2011; Naidoo 2009). The CBD of Cape Town and the Point Waterfront Development in Durban are marked by urban renewal projects, brokering staggering investments and facilitating massive local transformations.

There are simple but uncomfortable questions in all of this:

(a) In whose interest are such investments and accompanying renewal processes?

(b) To what extent does it reach the masses of poor people, expanding the economic base to create sustainable economic opportunities for those formerly excluded?

(c) What are the environmental costs of such growth and investment?

(d) How is the church participating in this conversation and positioning itself, or is it simply absent from it?

\subsubsection{New oppressions and ever-growing disparities: Between affirmative action and new marginalisations}

In the changing economic landscape, there is a slow shift from a race-based economy to a class-based economy. The new black elite benefits from the levelling of playing fields and the profits gained through Black Economic Empowerment. Too often, goes the critique, the same beneficiaries benefit repeatedly, whilst the masses remain out in the cold.

In her novel, Coconut (2007), Kopano Matlwa explores the minds of young black professionals who seek to embrace a new lifestyle and way of thinking, often in denial of or in conflict with their roots. There are shifts towards "whiteness", which Matlwa explores, that contribute to deepening disparities and new exclusions. Juxtaposing this new face of wealth and upward mobility is the cruelty of urban homelessness, increasingly evident in the faces of young black women and men, and to a lesser degree youth in pockets of white poverty. 
Migration to our cities, from both rural towns and across our borders, continues to fuel the number of people trapped in vicious cycles of homelessness, living in notorious hostels in the eastern suburbs of Johannesburg, or in sprawling informal settlements on the fringes of cities and towns. Voluntary sex work or forced prostitution, owing to different forms of human trafficking (Madlala-Routledge 2010), is also an expression of such new marginalisations.

\subsubsection{The impact of the economy on urban environmental quality}

Noise, air and river pollution, poor waste management, and poor sanitation all result from formal and informal developments taking place at unprecedented rates, and local urban infrastructure and the natural environment cannot keep up with the demands placed upon them. A vision of green cities that model sustainability, not only economically but also particularly environmentally, has not yet taken adequate root in South African planning and policy circles. The latest report of the United Nations Environment Programme demonstrates that the gross domestic product of South Africa grew by 24\% between 1990 and 2008, whilst the new Inclusive Wealth Index shows that South Africa's natural resource base shrank by 33\% during the same period (Tempelhoff 2012:2).

Theological education has a key responsibility to affirm creation and to foster human responsibility for the management of creation. The work of institutions such as the African Centre for Cities in Cape Town and the Sustainability Institute in Stellenbosch need to be acknowledged and integrated into theological curricula and the praxis of local churches.

\subsection{Religious changes and challenges}

Traditional city-centre churches faced the options of flight, death or creative transformation, and almost no inner-city church post-1994 was able to continue without change. Some sold their buildings to other denominations, some became mosques or warehouses for businesses, and some creatively adapted through painful processes of internal transformation. Others underwent internal transformation processes just to be co-opted again into "new" suburban agendas of the new elite.

At the same time, a proliferation of new inner-city churches changed the urban landscape, and people - mostly independent Pentecostal groupsnow gather for worship in shop-fronts, museums and school halls, or share space with traditional mainline churches (Zvomuya 2012).

African Initiated Churches have become more visible in city-centre areas post-1994, and now occupy some very central open spaces for worship, compared with the very marginal expressions pre-1994.

The suburban church continues to flourish in urban South Africa, sometimes connected to the broader urban church, but sometimes very self-sufficient in its independence from the rest of urban reality. 
Township churches remain connected to the lives of millions of urban residents, even if only through the ritualistic moments of baptisms, funerals and weddings. They experience a lack of institutional and financial capacity, struggle to embrace a strong urban agenda, and where they connect with their surrounding communities, it is usually by way of relief efforts that do not necessarily translate into longer-term developmental programmes.

Mega-churches traditionally emerged from suburbia, but now also occupy township and inner-city spaces. Although some mega-churches connect themselves to the realities of urban poverty, many others tend to brand themselves in ways that lure the middle classes seeking prosperity and the poor seeking instant healing. A relatively recent phenomenon is the so-called e-church, connecting people electronically through social media, and fostering spirituality within the virtual city.

Apart from Christian religious expressions, there is also a diversity of other religious expressions in urban areas, ranging from the main religions to smaller cults and esoteric experiences.

\section{Urban South Africa: Calling for liberating theological education}

\subsection{A call to incarnational theological education}

\subsubsection{Contextual immersions}

South Africa is the most urbanised country on the continent of Africa. The migration from rural South Africa and from beyond our borders continues on a daily basis. This often results in further suburbanisation and urban flight.

Much of what we know as theological education is not rooted in or shaped by urban contexts, although most of our reality is urban. At worst theological education tended to be anti-urban. In many schools of theology, it seeks to be "neutral" or "a-contextual". And where it proclaims to be contextual, it is often practised as the new orthodoxy with limited roots in contextual praxis, a contextuality that is not incarnational, a theological curriculum not grown from the soil of urban experience and hardship, an educational space void of diverse and marginal voices.

The Asian Theological Conference of 1979

asserted that every theology is conditioned by the class position and the class consciousness of the theologian. Hence a truly liberating theology must be the work of the Asian poor, who are struggling for true humanity... This does not exclude the so-called specialists in theology. With their knowledge they can complement the theologizing of the grass roots people. But their theologizing become authentic only when it is rooted in the history and struggle of the poor and the oppressed (De Santa Ana 1979:133). 
Our theologies are shaped by where we locate ourselves, and can never be ahistorical or a-contextual. If we immerse ourselves in urban contexts of vulnerability, it will shape our theological praxis differently.

\subsubsection{Theology as big as the city}

The kind of incarnation that is required of theological education is probably way beyond what traditional models of theological education would consider a part of its mandate. Theological education that fails to equip its students - who will probably end up working in divided African cities for the most part - to engage with urban realities meaningfully is impotent and irresponsible. It fails the students, the church, and the people of the city.

"A 'theology as big as the city', (also the title of a book by urban missiologist Ray Bakke (1997)), is a vision for theological education that will enable leaders to relate in an informed and robust manner with the diversities and complexities of cities, reflecting theologically on land, housing, health, sanitation, economics, urban infrastructure, democracy, race, class, gender, culture, art, religion, and space (virtual and physical)."

\section{$3.2 \mathrm{~A}$ call to be urban readers}

\subsubsection{Reading of texts and contexts}

Responsible pastoral praxis requires sensitive, wise and discerning urban readers who would reflect critically on various texts and contexts, on both bible and city. Theological education has the challenge of fostering a new generation of urbanists, that is, reflective urban practitioners. This would also require re-reading of texts, or, in the words of De Santa Ana (1979:125), a "re-making of history", a subversion of history, reading it also from below and not just from above.

Students of theology need to be able to analyse urban systems and powers, to analyse and understand their neighbourhoods, to read urban culture in all its diversity, to listen carefully in order to hear those without a voice, to make sense of the institutional composition of the communities in which they serve, to read and re-read the narratives of the city.

\subsubsection{A call to critical reflection in community}

Theological education needs to be assessed as to the extent to which it helps foster community and interconnectedness, instead of greater individualism and independence, both in personal lifestyle and in the manner in which it shapes churches, faith communities and local neighbourhoods.

Embracing our interdependence in the city will start with the discipline of reflecting critically, in community, on both bible and city. We have been helped by contextual theologies and postmodern theorists to understand that texts are never read neutrally, but through the lenses of our own cultures, faith traditions and experiences. Therefore, a responsible 
reading of texts and contexts would need to happen in community (Chopp 1991:86) with others who represent a different tradition, race, class, professional discipline or urban status, listening, reading, hearing, and responding together. Incarnating our theological education in particular contexts of suffering, and between worlds, we position ourselves as companions in community, and the very act of theological education "becomes a way of reweaving that community bond" (Palmer 1993:xx).

\subsubsection{Engagement with other disciplines}

In developing analytical skills and the ability to read the context well, and in reflecting theologically in community, theological education needs to become more intra- and interdisciplinary in its very nature. It needs to relate to and invite the insights of other disciplines: development studies, urban planning, social work, psychology, geography, sociology, political sciences, land economics, graphic arts, health sciences, and others.

If we affirm that the earth is the Lord's, and everything in it, then our theological enquiry needs to be as large as the city, and that requires ongoing critical conversation with all those partners that can help us understand more of the city or the world we live in.

\subsubsection{From need-driven to asset-driven approaches}

Our analyses of urban communities, if focusing only on need and deficiency, lead to pathological readings of urban areas that almost exclude the possibility of hopeful transformation. Responsible and transformative urban readers would develop readings of the city that understand the needs and challenges, but also affirm and insist on the assets and potentials that could become the building-blocks of sustainable, inside-out urban change (Kretzmann and McKnight 1993).

\subsection{A call to creative imagination}

\subsubsection{Sterile, rigid, uncreative}

Cities are dynamic organisms, always on the move, continuously reinventing themselves. They facilitate the mobility of human migration, subcultures, and brands. If we develop ministry strategies for local communities based on community analyses of three years ago, we might be completely unaligned with current challenges of the same community because of constant change.

In contrast though, churches are slow to change, conservative in nature, captives of institutionalised structures, and often absorbed by theological discourses that are sterile, rigid, uncreative and at best impotent.

Apart from the reality of the physical city, the reality of virtual cities and the emergence of Generation Y require theological education that will be robust in the manner in which it connects with the dynamic, mobile, and often harsh realities of its surrounds. 


\subsubsection{The urban cookbook: Engaging cities imaginatively}

In the past years, The urban cookbook (2008) has become one of my most valued theological resources, even though it is what the name says, a cookbook. It is a collection of street art, street food and street culture. So how does it challenge me theologically?

Firstly, it introduces people who are shaping urban culture through an intimate, almost intuitive, understanding of culture making and the dynamics of contemporary popular culture. It makes me wonder who our dialogical companions and interpreters of the city should be. How can we imagine shaping urban culture without entering into conversation with those who understand and shape urban culture innovatively on a daily basis?

Secondly, the collection in The urban cookbook suggests to me, in some cases more than others, a spirituality at work that has nothing to do with institutionalised religion. It made me wonder about the nature of our theological education - the extent to which it is co-opted by institutionalised religion, and the extent to which it fosters a critical, innovative and connected spirituality that can engage both institutionalised religion and popular culture in ways that are at once affirming, critical and transformational.

To what extent do we allow imaginative urban practices to inform and transform our theological praxis, so that we in return can engage, inform and help transform urban reality imaginatively? How do we create relationships of mutually imaginative convers(at)ion between theological education (church/faith communities) and urban culture?

\subsubsection{The art of imagineering: An essential task of theological education today}

I propose the art of imagineering as one of the most critical tasks not only of the urban church today, but also of theological education. "Imagineering" as a term was popularised by Walt Disney Imagineering in 1952, after being used in the 1940s by Alcoa to describe "its blending of imagination and engineering". Walt Disney Imagineering was created to draw together the most creative minds in the Disney group to imagine and pioneer their most audacious and exciting new ideas (Wikipedia 2012b).

Today "imagineering" is also used in organisational development as a term for strategic visioning and planning. One website describes it as

Imagination, Innovative Thinking, Creativity, Experience,

Understanding, Resourcefulness, Focus, Dedication, Belief, Faith and

Madness blend together to form a melting pot from which the most incredible ideas manifest (with a little bit of hard work and a lot of play) into reality.

The ability to imagine and engineer ideas to realise a desired outcome and meet specified criteria for practical purposes (Imagineering 2011). 
Theological education would do well to learn from and foster the art of imagineering with students, to blend "imagination... creativity, experience, understanding... dedication, belief, faith and madness" in ways that will

(a) re-imagine the story of churches, neighbourhoods, and theological education itself, from the future back;

(b) visualise the re-imagined stories concretely;

(c) identify and mobilise all the resources required to make that new story reality; and

(d) translate the visualised story into a strategy and action plan that will change the urban landscape.

If Disney can achieve it, why can the church that claims the power of the Spirit not live such hopeful and prophetic imagination (Brueggemann 1978; 1986)?

\subsection{A call to a holistic, earthy spirituality}

Is theological education rooted in healthy and connected spirituality that provides the soil for liberating praxis (McAfee Brown 1988)? It should remind itself often that theological reflection is only the second step after a "lived faith", in the description of Gutiérrez (1988:xxxiii-xxxiv), which will prevent the enterprise of theological education from losing its soul.

\subsubsection{A holistic spirituality connected to urban issues}

The challenge is for models of theological education that are deeply rooted in and connected to the complexities of urban reality. This requires a holistic, relevant and contextual spirituality, making sense of the work of the Spirit in the different spheres and layers of urban society. At the same time, it implies a vibrant, dynamic and innovative spirituality, mirroring the very nature of urbanity and allowing the energy and visions of grass-root movements to enthuse it.

Cities are living organisms and every urban place has its own "genius loci", or "brooding angel", or inherent spirituality. Our reflection on cities should therefore not only focus on the physical reality of the city, but also acknowledge the deeper roots or values that helped shape them over generations (Linthicum 1991:73-79; Norberg-Schultz 1980).

\subsubsection{An earthy spirituality speaking urban language}

Our theological education, for it to be liberated and liberating, needs roots in an earthy spirituality (Chopp 1991:69) that will connect to the physical and bodily forms of the city; retrieve and learn to speak the different language/s of the city, whether of diverse cultures, the streets, urban public places, or virtual spaces; and learn to see and celebrate beauty amidst urban pain. As Paul became Greek for the Greeks and Jew for the Jews, we need 
to foster models of theological education that are able to speak the language/s of the city, affirming the universality of God's grace.

\subsubsection{Between mysticism and resistance}

Dorothee Sölle (2001), in her amazing book, The silent cry, retrieves various sources of mysticism-nature, eroticism, suffering, communion, and joy - that helped inform and sustain acts of resistance and liberation throughout the centuries, in very different contexts of contest and pain.

Theological education that is not rooted in, and does not foster, a deep and robust spirituality of both mysticism and resistance would be unable to help imagine, guide, equip and sustain the varied and brave actions of faith that are required of contemporary ministry leaders. Theological education today needs to shape urban mystics that will root themselves in rituals and resources that can sustain acts of resistance and liberation in the city (Carretto 1982). Messer (1989:116-134) speaks of "political mystics" who integrate mysticism and resistance into their ministry praxis.

Having such integrated spiritualities at the heart of our theological praxis is the only way to retain the soul of the city and its people: fostering disciplines of compassion and reflection that affirm the soul of the city, as well as disciplines of resistance and action that will protect the city's soul from all those forces threatening to destroy it.

\subsection{A call to a prophetic-pastoral praxis}

Rooted in a holistic spirituality that embraces both mysticism and resistance, theological education could foster leadership that will deal with personal pastoral issues, as well as systemic prophetic issues. Cities call for a prophetic-pastoral praxis that is at once caring, serving and hospitable, but also critical, resistant and even confrontational.

\subsubsection{Sub-urban practice}

Suburban models of church often focus on the caring and hospitality of its members, good preaching, and lively, contemporary styles of worship, which in themselves are essential modes of ministry. They are often weak on the side of bold diaconal action, community development, advocacy, lobbying or prophetic witness.

In a country where HIV/AIDS destroys families and communities, where the number of orphaned and vulnerable children grows daily, where violence against women, children and the earth is not decreasing, and where land is heavily concentrated in the hands of a few at the expense of millions of landless people, stereotypical images of suburban practice cannot be reconciled with the radical implications of the gospel Jesus lived. Can we imagine a prophetic-pastoral praxis that transforms our suburban ministry praxis into a $s u b$-urban praxis: an engagement of solidarity on the urban 
fringes, from below, where people and places are forgotten and silent in the sub-city of Tracy Chapman (1989)?

People say it doesn't exist

'Cause no one would like to admit

That there is a city underground

Where people live everyday

Off the waste and decay

Off the discards of their fellow man [sic].

3.5.2 Pastoral praxis that is caring and prophetic, hospitable and just

A prophetic-pastoral practice would imagine brave alternatives to the fault-lines running through the city. It would combine celebration and resistance, healing and protest. It will be hospitable in its embrace of strangers and just in the manner in which it protests acts against strangers. It would break the silence and allow the voices of strangers/neighbours to interrupt our neatly constructed theological discourses. It would learn from the poor and those on the urban margins, as the liberation of the church "is through the Christian community's placing itself at the service of the poor and for the sake of justice" (De Santa Ana 1979:68-69). And in being informed and liberated by the poor, its own pastoral praxis would become authentic and liberating.

\subsection{A call to healthy communities}

Cities in their fragmentation and woundedness call for a vision of healthy and interconnected communities that will display characteristics of resilience, self-reliance and fair access to basic resources for sustainable livelihoods. What constitutes a healthy community, what do leaders require to facilitate such communities, and what should our theological curricula therefore contain? I propose these three questions as fundamental in designing curricula with the possibility of mediating transformation and wholeness.

\subsubsection{Congregation/church and community/world}

The Anglican Bishop of the Diocese of Natal, Bp. Rubin Philip, contrasts a theology of the Word with a theology of the world. How do we prepare students of theology and ministry not only for congregational ministry, but also for community ministry; not only to preach the Word, but also to flesh out the claims of the gospel in the world? How do we help foster a theology and vision of community that affirms our interdependence and interconnectedness as body of Christ, humanity and creation?

\subsubsection{Fostering community}

We cannot foster community in the world, if our theological education has not modelled the fostering of community in its method of teaching. Community here refers to intimacy, reciprocity and belonging (people; Boff 1986:5), but it also refers to a particular neighbourhood (place). 
I propose that theological education will enable people to participate in and/or facilitate three types of community meaningfully:

(a) Theological education should prepare people to create communities of disciples, that is, faith communities that are not captive to institutional models transferred from one generation to the other, but rooted in, vibrant and responsive to the urban contexts in which they find themselves (churches, faith-based organisations, intentional communities, base ecclesial communities), and able to practise "a new presence of church ... with new tasks and styles" (Boff 1986:60).

(b) Secondly, theological education should equip people to create a multiplicity of pastoral or caring communities on the urban margins, deeply connected to the pain, the poor and the voiceless of the city. Greenway (2000:188) argues why street people need pastors too. Millions of refugees, commercial sex workers, orphaned children, business tycoons, artists and bohemians, gays and lesbians, ama-kipkips and smarteez, yearn to experience the warmth of relationships in which they can belong and be cared for.

(c) Thirdly, theological education should equip people to create and/or participate in citizens' communities, that is, communities in solidarity with particular areas of challenge or contest in the city, whether a local community forum, the relocation of people from an informal settlement, the closure of a local basic health care facility, the necessity of affordable infrastructure for informal traders, the accessibility of antiretroviral medicine for people living with HIV/AIDS, or the work of building healthy and sustainable urban neighbourhoods.

In reflecting on base ecclesial communities and their acts of citizenship, Boff (1986:43-44) speaks of them as birthing a new Christian with a new language and "a citizen, too, and a critical, participating, democratic citizen - the agent not of a pre-established system but of a new social hope".

\subsection{A call to become liberating, entrepreneurial institutions}

\subsubsection{Church as liberating, caring local institution}

One of the building-blocks of healthy local communities is the active, responsive and participating presence of caring local institutions, that is, institutions that are locally rooted and owned, and working continuously to provide accessible infrastructure for local people.

This is a challenge for the church's self-understanding. The church existing for itself and its members will often be an institutionalised church that does not mediate liberation or caring to the surrounding neighbourhoods. But a 
church of the neighbourhoods (De Santa Ana 1979:4) in which it is located will be sensitive to the local neighbourhood's struggles, and will shape its ministry response accordingly.

\subsubsection{Church as incubating, entrepreneurial institution}

The church as local caring institution will offer its own infrastructure and/or develop new infrastructure, that is, in all those areas where local community members lack such infrastructure. It could take the form of health care centres, legal aid centres, different educational opportunities, employment advice bureaus, recreational facilities, and additional basic access to water, sanitation and electricity.

For theological education to enable ministry praxis that is entrepreneurial, it would need to foster an entrepreneurial vision of church in relation to society, combined with skills in project management and organisational development, and encouragement to students of theology to equip themselves further in specific areas of social challenge most prevalent in local contexts, whether HIV/AIDS, child-care, land and housing, or small enterprise development.

\section{A spirituality and praxis of theological education: With roots and wings}

Drawing from Klippies Kritzinger (2002) as a metaphor for theological engagement in the city, I suggest a spirituality and praxis of theological education that has roots and wings (the Jewish proverb often suggested by Klippies), that is incarnational, communal, and missional.

A prerequisite for liberating theological education - that is, liberating the praxis of theological education, as well as serving as an agent of liberation in church and urban society - is a spirituality that will root people in lived faith (the prerequisite for doing theology-see Gutiérrez 1988:xxxiii-xxxiv) and specific local contexts, whilst giving them wings of freedom (Chopp 1991:86) to explore new experiences, to enter new solidarities, and to innovate new praxes.

\subsection{Living faith: Incarnating in and between worlds}

Klippies is a metaphor for urban theological engagement, having continuously incarnated his life, faith and ministry in and between different traditions, religions, classes, races, and publics. I do not quote extensively from his writing in this article, but reflect the uniquely personal resources of spirituality that I have gained from his person and praxis.

As a white Reformed Afrikaner/African, he learnt from Steven Bantu Biko, when most other white Afrikaners did not. He and his family decided to live in Proclamation Hill, a working-class white suburb in those days, which was not where professors normally lived. He was in dialogue with people of 
other faiths and together with them visited and supported imprisoned activists and their families when he was a minister of the Reformed Church in Africa in Laudium, an Indian neighbourhood.

I discovered someone with a deep and unwavering commitment to Christ, but then a Christ who stood incarnated in and between worlds, at the same time humble and confident, healer of the blind and protester in the temple. The incarnation is to flesh out the gospel in concrete situations of challenge and hope, to stand with those who are vulnerable, and to mediate between power and resources, between sacred and profane, embracing contemplation and action as two sides of the same coin.

Kritzinger often distinguishes in his preaching between "power over" and "power with" (see Boff 1986:60 on the function of facilitators of base ecclesial communities). The incarnation models a different kind of power, that is, power from below, power alongside, power with, sharing/shared power, common power. If knowledge is power, we have to critically engage the kind of knowledge/power that is practised, modelled and transferred through theological education. Parker Palmer (1993:8) speaks of the purpose of our educational pursuits, not being about "exploiting and manipulating creation but about recreating the world to itself".

If our desire for knowledge comes from a place of control or curiosity that seeks power over others, it is "exploiting ... creation". But if our knowledge comes from a place of love and compassion-knowing and being known in our journeys in, with and between worlds - it will seek power with others, especially with those who are powerless.

Where and how we root ourselves will determine the nature and outcomes of our theological education. Incarnating theological education in and between places, as companion of the city, driven by love and compassion, desiring to recreate the world to itself and to be known ourselves in the process, will change the nature and outcomes of theological education.

\subsection{Living faith: Communality of table and tree}

I have been deeply shaped by the way in which Klippies creates liberating and energising space around the communion table. Instead of impotent ritualistic captivity, the table becomes a moment of lively, liberating ritual, mediating the deep identification of Jesus with human reality every time we eat and drink, affirming our mutual interdependence as people and with creation. His practice of communion indeed fosters holistic, earthy spirituality.

At the same time deeply personal and profoundly communal, communion becomes a place that energises and enables a living faith. Through personal and communal reflection, confession, worship, dance and proclamation, the saving grace of Christ is announced every time, as the cross calls us to reconciled and resurrected lives and communities. Klippies, in his life and theological reflection, draws from the re-enacted death and 
resurrection of Christ at the communion table, always drawing us into deeper solidarity with the many sufferings of our world, but always reminding us too of the possibility of multiple resurrections that Christ seeks to mediate.

Just as the communion table has been a central tenet in his theological and missional reflection, the tree (Kritzinger 2009) as a symbol of life and our interconnectedness to creation has been another central category in his thinking and practice, both table and tree reconnecting us to life, to the Creator, to creation, to the land, and to each other.

If theological education can create and foster spaces drawing from table and tree, our theologies and churches will display a greater sense of interdependence and mutuality; embrace life as gift of beauty, nourishment and abundance; invite all people to new tables; whilst passionately guarding the household of creation and humanity, regardless of our differences, in order to thwart the thief out to rob the nourishing sources meant to sustain the earth and humanity alike.

The kind of knowledge we are called to is "a knowledge that does not distance us from the world but brings us into community, face to face" (Palmer 1993:16). How do we foster practices in and through theological education that will connect us that closely to community, to the other?

A knowledge that heals and makes whole will come as we look creation in the eyes and allow it to look back, not only searching nature but allowing it to search us as well. This will be perfect knowledge, Paul says, for "then I shall know as fully as I am known". The "objects" of our knowledge will no longer be objects but beings with personal faces, related to us in a community of being, calling us into mutuality and accountability. It will be as the poet Rilke says “... there is no place at all that isn't looking at youyou must change your life" (Palmer 1993:16).

The table and the tree simply remind us of the beauty and abundance of God's creation, of our belonging to others; they remind us too of those who are not at the table yet, of dying trees and exploited land; it calls us to healing and wholeness; it charges us to respond and be accountable.

Education of this sort means more than teaching the facts and learning the reasons so we can manipulate life toward our ends. It means being drawn into personal responsiveness and accountability to each other and the world of which we are a part (Palmer 1993:14-15).

And instead of subduing the city to our preconceived notions of knowledge, we become companions in community, discovering abundance and beauty, and creating new tables. 


\subsection{Living faith: energised for mission}

Throughout his ministry, Klippies' quiet insistence on a missional life, expressed in words, preaching, teaching, administrative responsibilities, and choices of lifestyle, energised many around him for mission.

Living in a working-class white neighbourhood, he was the minister of the Reformed Church in Africa in Laudium, an Indian township in the west of the city. Later he was part of the Reformed Confessing Community, an intentional community of Reformed believers seeking to cross racial barriers in fellowship at the height of apartheid. Later, this community was incorporated into the new Melodi ya Tshwane Uniting Reformed Church in Southern Africa, specifically started as an intercultural community, and Klippies was one of the founding ministers. Each of these faith communities of which he was pastor was essentially a missional community seeking to engage the world around it creatively, prophetically and in a faithful search to be true to the gospel of Christ.

Drawing from the gift of communion, and reminding us that we are members of the larger body of Christ, humanity and creation, he encouraged people to a missional engagement in the world that could express itself in different ways. The missional engagement of Klippies embraces evangelising and re-evangelising; teaching and dialogue; intercultural and interfaith conversation; justice, humanity, and freedom; earth keeping; development; peace and reconciliation (Kritzinger 2010:4).

With a foot in the academy as a good teacher and administrator, a foot in the church as pastor and preacher, and a foot in the world as citizen and prophet, Klippies models a three-footed missional engagement in two different ways: between academy, and church and city/society (Botha 2009:8) he lives his life; and he is seeking to live it in an incarnational, communal and missional way.

His spirituality integrates mysticism and resistance, prayer and politics, heaven and earth, reflection and action, with a prior commitment to liberation born from a lived faith. His spirituality evokes mission that will affirm the integrity and dignity of all human beings and of creation. The incarnational and communal dimensions of spirituality will always invite new expressions of missional engagement working for wholeness, justice and peace in all of creation. Such should be the impetus of theological education.

\section{Conclusion: Imagining theological education in the Gauteng city-region}

The Gauteng Province is the economic powerhouse of Africa. It consists of an interdependent network of metropolitan municipalities, cities and towns, also known as the Gauteng city-region. The cities of Johannesburg, Soweto and Pretoria all fall within this growing metropolitan hub. Statistics South Africa's Community Survey of 2007 estimated the Gauteng population to have grown 
to 10667579 (Gauteng City-Region Observatory n.d.). Projections are that the Gauteng city-region will be one of the twenty largest city regions in the world by 2020 , with a population close to twenty million people.

This city-region hosts a number of institutions for theological education. However, the city is not necessarily intentionally on their agendas, nor does it necessarily shape the way they reflect theologically. Being located in one of the fastest-growing metropolitan regions in the world, with some of the greatest disparities between poor and rich in the world, the central proposals of this article are that

(a) theological education should be more deliberate and intentional in the manner in which it positions itself at the urban crossroads;

(b) the city could serve as a powerful resource to help liberate theological education; and

(c) that theological education growing from a mutually interdependent relationship with the city could become liberating in how it accompanies individuals, families, neighbourhoods, and larger urban processes and discourses, towards places of wholeness.

\subsection{Connected to each other, connected to the city}

Instead of working in isolation and competition, greater connectedness between key institutions for theological education, as interdependent communities of learning and action, rooted in urban contexts, could facilitate new synergies and transformational urban leadership development. For the purpose of this article, I will refer to four institutions that could start to embrace the city together as locus of theological education, simply because of their overlaps with Klippies' engagement.

\subsubsection{University of South Africa}

Klippies Kritzinger has taught missiology at the University of South Africa (Unisa) since 1982. After being Head of the Department of Missiology, Klippies was Dean of the Faculty of Theology and Religious Studies from 1999 to 2001. As a contextual theologian deeply influenced by Black Theology and the thinking of people like Biko, Klippies' contribution to the theological curriculum and formation of students of missiology at Unisa has expressed the emphases of these theological and philosophical traditions.

He has been instrumental in facilitating a partnership between the university and the Institute for Urban Ministry, a small grass-root institution promoting urban theological education, intuitively understanding the importance of the city in theological reflection. At a stage when the institute was only a dream on the margins, Klippies encouraged it to develop a certificate programme in urban ministry. This eventually led to the creation of three postgraduate degrees specialising in urban ministry and accredited by Unisa. 


\subsubsection{Institute for Urban Ministry}

The Institute for Urban Ministry (IUM) ${ }^{2}$ grew from the ecumenical partnership of the Tshwane Leadership Foundation. ${ }^{3}$ Recognising the lack of an urban focus in institutions for theological education, IUM started to develop contextual programmes in urban theology and ministry. It designed and developed urban curricula accredited by Unisa (and now also the University of Pretoria). This creative collaboration between a large tertiary institution and a community-based knowledge institution, both equally serious about theological education, but bringing very different strengths to the table, has become an innovative model for theological education. Were it not for the important role of catalyst and broker that Klippies played, this partnership might never have developed.

Unfortunately, owing to policy changes in the higher education system, the agreement between Unisa and IUM had to be terminated at the end of 2010. It compromised the ongoing partnership between these two institutions.

\subsubsection{Northern Theological Seminary}

The Northern Theological Seminary (NTS) was created to prepare students of the Uniting Reformed Church for ministry. Klippies Kritzinger was tasked with establishing the NTS, in response to the vacuum left by the closure of the former Turfloop campus in Polokwane.

The seminary at inception was hosted in Sediba House, an inner-city building that combined social housing, various community ministries and start-up social enterprises. Full-time students of the seminary for some time lived in The Foundation, a student-housing facility in the inner city, situated next to Sediba House. And both buildings were situated next to the church property jointly owned by the Melodi ya Tshwane Uniting Reformed Church and the Dutch Reformed Church of Pretoria. From the perspective of an incarnational urban approach to theological education, this was perhaps the "ideal campus".

Living in the inner city obviously provided students with an urban base from which to do theology. The context provided an opportunity to do theology at the interface with community development, cultural diversity, the ecumenical church, surrounding government institutions, and a range of social challenges concentrated in the inner city. The question, however, is whether the inner city was a coincidental location for the NTS, or was it a laboratory of choice for liberating and transformational theological education?

A later development was the creation of a partnership between the NTS and the University of Pretoria. As a result, the seminary was moved to be in closer proximity to the university, but also to have an asset of its own as compared with paying a monthly rental to a landlord. Unfortunately, this

2 http://www.ium.org.za/.

3 http://www.tlf.org.za/. 
meant giving up its strategic inner-city location. Could this have been a lost opportunity?

Klippies played a critical role in enabling the new partnership between NTS and University of Pretoria, once again telling of his ability to transcend racial, class and ecclesial boundaries, as well as boundaries between competing institutions.

\subsubsection{University of Pretoria}

In the case of the University of Pretoria, urban realities are hardly explored as part of the theological curricula. One module is offered on "church and city". The theological faculty has to consider preparing students more deliberately for the range of urban contexts in which they will find themselves ministering, ranging from sprawling townships and informal settlements to wealthy security estates; from decaying inner cities to well-established urban suburbs; from the streets to the board-rooms; each offering unique contexts of urban change and challenge.

The existence of the town and regional planning, and architecture departments as neighbours to the Faculty of Theology should perhaps not be regarded as coincidence, but as possible gifts for innovative urban engagement. The university itself needs to reflect on the particular role it can play, with its vast intellectual, human and physical resources, in the life and transformation of urban realities generally, but more particularly in the realities of vulnerable people and places in the city that is its home.

The Faculty of Theology, if taking Cox's assertion (1965:114-125) that the church is meant to be the diakonos of the city seriously, could play a facilitating role for such a critical and timely conversation. At the same time, this faculty could also facilitate multiple conversations in which the voices of those on the urban margins could disturb, inform and penetrate theological and other curricula on campus.

\subsection{An interdependent, intra- and interdisciplinary, and innovative urban cluster for theological education}

This article concludes by proposing an urban cluster for theological education that will find roots in the city and be intentional about the city as laboratory for immersion, analysis, reflection, dialogue, and action.

It proposes an interdependent cluster-starting with the above institutions, but not exclusively - that will overcome competition, and foster synergy and cooperation.

It proposes an intra- and interdisciplinary cluster that will overcome disciplinary fragmentation - between theology and city planning; between missiology, practical theology and ethics - and rather foster holistic and integrated action and reflection.

It proposes a cluster focusing on innovation in urban engagements, that is, 
- how the city becomes a studio for immersion, analysis, reflection and action (the nature of our research methodologies);

- how liberating conversations can be constructed between theological reflection, contextual realities, and urban people, translating theology into the city, and relating the city to theology;

- how diverse and often unheard voices can inform the theological conversation; and

- how to design and implement transformative urban praxes, documented as good practices, and replicated in contexts elsewhere.

\section{References}

Adz, K. 2008. The urban cookbook: Creative recipes for the graffiti generation. London: Thames \& Hudson.

Bakke, R. 1997. A theology as big as the city. Downers Grove, Ill.: InterVarsity Press.

Ben, A. 2011. Gautrain investment strategy.

http://www.skyrise.co.za/articles/gautrain-investment-strategy [accessed 15 Nov. 2012].

Boff, L. 1986. Ecclesiogenesis: The base communities reinvent the church. Maryknoll, N.Y.: Orbis Books.

Botha, N. 2009. Congratulations from the General Secretary: Special appreciation and acknowledgements. Missionalia 37(3), November:8.

Bremner, L. 2004. Johannesburg: One city, colliding worlds. Johannesburg: STE Publishers.

Brueggemann, W. 1978. The prophetic imagination. Philadelphia, Pa.: Fortress Press.

Brueggemann, W. 1986. Hopeful imagination: Prophetic voices in exile. Philadelphia, Pa:: Fortress Press.

Carretto, C. 1982. The desert in the city. New York: Crossroad.

Chapman, T. 1989. Sub-city, in Crossroads (Elektra Records).

Chopp, R.S. 1991. Situating the structure: Prophetic feminism and theological education, in Shifting boundaries: Contextual approaches to the structure of theological education, edited by B.G. Wheeler and E. Farley. Louisville, Ky.: Westminster/John Knox:67-90.

Cox, H. 1965. The secular city: Secularization and urbanization in theological perspective. New York: Collier Books.

Davey, A. 2001. Urban Christianity and global order: Theological resources for an urban future. London: SPCK. 
De Beer, S.F. 2008. Contesting inner-city space: Global trends, local exclusion/s and an alternative Christian spatial praxis. Missionalia 36(2/3),

August/November:181-207.

Department of Cooperative Governance and Traditional Affairs see South Department of Cooperative Governance and Traditional Affairs.

De Santa Ana, J. (ed.) 1979. Towards a church of the poor: The work of an ecumenical group on the church and the poor. Geneva: WCC.

De Vos, P. 21 April 2012. Wie noem jy wit?'n Les vir “lefties”. Beeld, Saturday:supp. 5.

Gauteng City-Region Observatory. N.d. About the GCR. http://www.gcro.ac.za/about-gcr/overview [accessed 14 Nov. 2012].

Greenway, R.S. 2000. Ministering to street people, in Cities: Missions' new frontier, edited by R.S. Greenway and T.M. Monsma. $2^{\text {nd }}$ edition. Grand Rapids, Mich.: Zondervan:180-190.

Gutiérrez, G. 1988. A theology of liberation: History, politics, and salvation. Maryknoll, N.Y.: Orbis Books.

Holland, H. and Roberts, A. 2002. From Jo'burg to Jozi: Stories about Africa's infamous city. Johannesburg: Penguin.

Huchzermeyer, M. and Karam, A. 2006. Informal settlements: A perpetual challenge? Cape Town: UCT Press.

Imagineering. 2011. http://www.imagineering.co.za/ [accessed 14 Nov. 2012].

Kretzmann, J.P. and McKnight, J.L. 1993. Building communities from the inside out: A path toward finding and mobilizing a community's assets. Evanston, Ill.: Center for Urban Affairs and Policy Research.

Kritzinger, J.N.J. 2002. A question of mission-A mission of questions. Missionalia 30(1), December:144-173.

Kritzinger, J.N.J. 2009. Tree-planting liturgy: Creative space. Missionalia 37(3), November:153-156.

Kritzinger, J.N.J. 2010. Intercultural learning for Christian ministry. (Paper read at the University of South Africa postgraduate seminar in Wiedenest, Germany, 23. September 2010). (Unpublished study material).

Lekota, P. 22-28 June 2012. Parliament for the party, not for the people. Mail \& Guardian, 21 June 2012:37.

Linthicum, R.C. 1991. City of God, city of Satan: A biblical theology of the urban church. Grand Rapids, Mich.: Zondervan.

Madlala-Routledge, M. 6 June 2010. Don't let sex slavery turn South Africa into a pimp state. Sunday Times.

http:/www.timeslive.co.za/opinion/letters/article488710.ece/Dont-let-sex-slavery -turn-South-Africa-into-a-pimp-state [accessed 29 Nov. 2012].

Matlwa, K. 2007. Coconut. Auckland Park: Jacana.

McAfee Brown, R. 1988. Spirituality and liberation: Overcoming the great fallacy. Philadelphia, Pa.: Westminster Press. 
Messer, D.E. 1989. Contemporary images of Christian ministry. Nashville, Tenn.: Abingdon Press.

Naidoo, B. 2009. Gautrain project to create 148000 jobs in next 20 years. http://www.engineeringnews.co.za/article/gautrain-project-to-create-148-000-job s-in-next-20-years-2009-03-17 [accessed 15 Nov. 2012].

Nel, E. and Binns, T. 2001. Initiating “developmental local government" in South Africa: Evolving local economic development policy. Regional Studies 35(4):355-362.

Norberg-Schulz, C. 1980. Genius loci: Towards a phenomenology of architecture. New York: Rizzoli.

Palmer, P.J. 1993. To know as we are known: Education as a spiritual journey. San Francisco, Calif:: HarperOne.

Parliamentary Monitoring Group. 2011. North West struggling municipalities: Hearings. http://www.pmg.org.za/report/20111123-maquassi-hills-local-municipality-vente rsdorp-local-municipality-and- [accessed 14 Nov. 2012].

Serrao, A. and SAPA (South African Press Association). 2012. E-tolls: Cosatu call to arms.

http://www.iol.co.za/motoring/industry-news/e-tolls-cosatu-call-to-arms-1.12784 73\#.UKPsfmccD2c [accessed 14 Nov. 2012].

Shaw, A. 5 September 2005. The impact of Gautrain. Business Day, Monday:11.

Sibalukhulu, N. 20 April 2012. SA's electoral system fails the people. Mail \& Guardian, Friday:34.

Sölle, D. 2001. The silent cry: Mysticism and resistance. Minneapolis, Minn.: Fortress Press.

Sosibo, K. 23 March 2012. Council of Churches in the wilderness. Mail \& Guardian, Friday. http://mg.co.za/article/2012-03-23-council-of-churches-in-wilderness [accessed 14 Nov. 2012].

South Africa. Department of Cooperative Governance and Traditional Affairs. N.d. How will boundaries be decided?

http://www.cogta.gov.za/subwebsites/publications/dermacation/dm7.htm [accessed 14 Nov. 2012].

Swilling, M., Humphries, R. and Shubane, K. 1991. Apartheid city in transition. Cape Town: Oxford University Press.

Tempelhoff, E. 18 June 2012. Al groei BBP, ly land se omgewing. Beeld, Monday. http://www.beeld.com/Wereld/Nuus/Al-groei-BBP-ly-land-se-omgewing-20120 618 [accessed 29 Nov. 2012].

Venter, Z. 2011b. Shacks: Council man in contempt of court. http://www.iol.co.za/news/crime-courts/shacks-council-man-in-contempt-1.1138 829 [accessed 14 Nov. 2012].

Venter, Z. 2011a. Solution in sight to plight of homeless. http://www.iol.co.za/news/south-africa/gauteng/solution-in-sight-to-plight-of-ho meless-1.1105079\#.UKPmbGccD2d [accessed 14 Nov. 2012]. 